\title{
Protection of Indonesian Migrant Workers while Working Abroad
}

\author{
Dede Supenti ${ }^{1}$, Zudan Arief Fakrulloh ${ }^{2}$ \\ Student at Doctoral of Law, Universitas Borobudur Jakarta
}

\{dedeunbor@gmail.com ${ }^{1}$, cclsis@yahoo.com² $\}$

\begin{abstract}
The constitution mandates that the state guarantees its citizens the right to work and a decent living for humanity. Work is a human right that must be upheld, respected, and guaranteed to be upheld. Likewise, every citizen has the right to seek a decent living abroad as a migrant worker. Against Indonesian migrant workers while working abroad. For this reason, the state is also obliged to protect all Indonesian citizens both inside and outside the territory of the Republic of Indonesia as stated in the fourth paragraph of the Preamble to the Constitution of the Republic of Indonesia. Protection of migrant workers while working abroad is the state's obligation to protect its citizens. This protection aims to ensure the fulfillment and enforcement of human rights as Indonesian citizens and migrant workers, as well as ensuring legal, economic, and social protection.
\end{abstract}

Keywords: Protection; Indonesian Migrant Workers; Work; Overseas

\section{Introduction}

The 1945 Constitution of the Republic of Indonesia, Article 27 paragraph (2) which states that every "Indonesian citizen has the right to work and a decent living for humanity". This means that indirectly, the state, in this case, the government, is obliged to guarantee every citizen to be able to work according to their interests and abilities.

Work is a human right that must be upheld, respected, and guaranteed to be upheld. However, the fact is, the government has not been able to provide jobs as mandated by this article, so that economically many people are concerned and cause many to seek work abroad, and choose to try their luck there to become Indonesian Migrant Workers (TKI) or the popular term Indonesian migrant workers.

Concerning the problem of migrant workers, the Government has issued several laws and regulations, especially implementing regulations and several policies to protect migrant workers who work abroad must be protected from human trafficking, including slavery and forced labor, victims of violence, abuse, crime. on human dignity, as well as other treatment that violates human rights.

The importance of protection for Indonesian migrant workers who work abroad because Indonesia is a state based on law, so that the state is obliged to protect all Indonesian citizens both in the territory of the Unitary State of the Republic of Indonesia (NKRI) and outside the territory of the Republic of Indonesia listed in the fourth paragraph of the Preamble to the Basic Law The Republic of Indonesia (UUD NRI) is further regulated in Article 28A which reads "Every person has the right to live and has the right to maintain his life and life", so it 
can be said that the Republic of Indonesia will protect the right to life, as well as the right to defend the life and lives of all citizens Indonesia. There is no exception in this case the state will protect citizens who are inside or outside the territory of the Unitary State of Indonesia.

In 2012, the Government of Indonesia has shown a commitment to protecting citizens who work abroad (migrant workers) bypassing Law Number 6 of 2012 which ratifies the International Convention on the Protection of the Rights of All Migrant Workers and Members of Their Families (International Convention on the Protection of the Rights of All Migrant Workers and Members of Their Families), where the convention not only protects the rights of migrant workers but also family members of these workers. What is meant by family members can consist of the mother, father, husband/wife, or even children of the worker himself, especially not a few migrant workers who are married and have children where they work.

Then the Government, to guarantee rights, opportunities, and protect every citizen without discrimination to obtain a decent job and income, both at home and abroad under their expertise, skills, talents, interests, and abilities, the issuance of a Law, Law Number 18 of 2017 concerning Protection of Indonesian Migrant Workers.

The protection of Indonesian Migrant Workers is aimed at ensuring the fulfillment and enforcement of human rights as citizens and Indonesian Migrant Workers and ensuring legal, economic, and social protection for Indonesian Migrant Workers and their families [1].

Starting from the problems related to legal protection for Indonesian migrant workers while working abroad, of course, there must be efforts from the government to provide protection. Therefore, it is important to study and discuss the issue of protecting Indonesian migrant workers while working abroad.

\section{Research Problem}

Based on the background described above, the formulation of this research problem can be formulated as follows:

"How are Indonesian migrant workers protected while working abroad?"

\section{Research Method}

This research is normative legal research. Normative research is often called doctrinal research, which is research whose object of study is legal documents and library materials [2]. The approach used in this research is a statute approach and a conceptual approach [3].

\section{Results and Discussion}

In national development, the workforce has a very important role and position for actors and development goals. Following the role and position of the workforce, it is necessary to develop manpower to increase its quality and contribution to development, as well as protect their rights and interests under human dignity. Manpower development must be regulated in such a way so that basic rights and protections for workers can be fulfilled [4].

The legal basis for the protection of Indonesian Migrant Workers includes: 
a. The 1945 Constitution of the Republic of Indonesia.

b. Law Number 13 the Year 2003 concerning Manpower

c. Law Number 6 of 2012 concerning Ratification of the International Convention on the Protection of the Rights of All Migrant Workers and Members of Their Families.

d. Law Number 18 the Year 2017 concerning Protection of Indonesian Migrant Workers.

e. Law Number 39 the Year 1999 regarding Human Rights.

Law Number 13 of 2003 concerning Manpower, Article 1 point 3 states that "A worker/laborer is any person who works and receives wages or other forms of remuneration".

The word migrant itself comes from the word "migration" which means "moving from one place to another." This movement of people can take place within a country - this is known as "internal migration". Migration can also occur when people move from their home country to another country - this is referred to as "external migration" or "emigration" [5]. Therefore, what is meant by migrant workers is any person who moves from one place to another, either within the country or between countries to work for a fee or remuneration.

Migrant workers or often referred to as migrant workers are "a person who is to be engaged, is engaged or has been engaged in a remunerated activity in a State of which he or she is not a national" [6]. According to Article 1 number 2 Law no. 18 of 2017, Indonesian Migrant Workers are every Indonesian citizen who will be, are currently doing, or have done work with wages outside the territory of the Republic of Indonesia. Migrant workers are people who migrate from their birthplace to another place and then work in the new place for a relatively permanent period.

In the Migrant Workers Convention 1975, Article 11, the term migrant worker means a person who has migrated or who has migrated from one country to another for work other than self-employment and includes anyone who is permitted to enter regularly as a migrant worker. Meanwhile, according to the 1990 UN Migrant Workers Convention, Article 2, the term "migrant worker" refers to a person who will, is currently, or has been carrying out paid activities in a country where he is not a citizen. The provisions of Article 34 of Law Number 13 the Year 2003 concerning Manpower have mandated that provisions regarding the protection of overseas workers or Indonesian Migrant Workers shall be regulated by law. For this reason, the government issued Law Number 18 of 2017 concerning the Protection of Indonesian Migrant Workers.

Protection of Indonesian Migrant Workers is all efforts to protect the interests of Prospective Indonesian Migrant Workers and/or Indonesian Migrant Workers and their families in ensuring the fulfillment of their rights in all activities before work, during work, and after working in legal, economic, and social aspects [7]. Meanwhile, Protection During Work is all activities to protect Indonesian Migrant Workers and their family members abroad [8]. The protection of migrant workers is based on the fact that every worker or laborer has the right to receive protection for his / her safety in carrying out work for the welfare of life and to increase national productivity. Also, every other person who is in the workplace, even if he is not a worker/laborer, needs to be guaranteed his safety [9].

Protection of Indonesian Migrant Workers has the following principles: $a$. cohesiveness; $b$. equal rights; c. recognition of human dignity and rights; d. democracy; e. social justice; f. gender equality and justice; g. non-discrimination; h. anti-human trafficking; i. transparency; j. accountability; and k. sustainable [10].

Protection for citizens is a citizen' right guaranteed by law. Abroad, the protection of Indonesian Migrant Workers is carried out by the Representative of the Government of 
Indonesia, the State of the Republic of Indonesia, in this case, the Embassy of the Republic of Indonesia (KBRI) which is based on statutory regulations, as well as international law and customs. The Embassy of the Republic of Indonesia provides guidance and supervision to the supervisory representatives of private Indonesian migrant workers and Indonesian migrant workers who are stationed abroad.

The protection of Indonesian Migrant Workers is intended to guarantee the basic rights of workers and guarantee equal opportunity and treatment without discrimination to realize the welfare of workers/laborers and their families in the framework of just industrial relations.

On 18 December 1990, the United Nations General Assembly adopted the International Convention of the Protection of the Right of Migrant Workers and Members of Their Family. The 1990 Migrant Workers Convention entered into force on 1 July 2003, after being ratified by 20 countries. In Indonesia itself, the 1990 Migrant Convention was ratified by the Indonesian Parliament and ratified on May 12, 2012. The ratification was promulgated into Law Number 6 of 2012 and Indonesia became the 46th country to ratify the 1990 Migrant Convention. Until October 2018, 54 countries have ratified this convention. The rights of migrant workers and their families as stipulated in the 1990 Convention are as follows:

a. Free to leave any country including the country of origin and the right to return to the country of origin (Article 8).

b. The right to life is protected by law (Article 9)

c. Not subject to torture and other cruel, inhuman, and degrading legal treatment (Article 10).

d. Not allowed to be enslaved/enslaved or doing forced labor (Article 11).

e. The right to freedom of thought, conscience, and religion (Article 12)

f. Right to freedom of expression both orally and in writing (Article 13)

g. Right to freedom of communication with family and personal matters (Article 14)

h. Entitled to property (Article 15).

i. Right to liberty and security of person (art. 16)

j. Right for humane treatment if deprived of their liberty (Article 17)

k. Have equal rights with nationals of the State of destination before the courts and tribunals (Article 18)

1. There are no punishments that are more severe than those applicable to a criminal act due to an act of negligence that did not constitute a criminal offense under national and international law at the time the act was committed (Article 19)

m. Not imprisoned for failure to fulfill a contractual obligation (Article 20)

n. Receive protection for documents he carries, from confiscation, destruction except by authorized government officials (Article 21)

o. Not subject to mass evictions (Article 22)

p. Have the option of requesting the protection and assistance of consular or diplomatic officials from their home country or countries that represent the interests of their home countries (Article 23).

q. Recognized before the law (Article 24).

r. Receive the same rights as citizens of the destination country in terms of remuneration (Article 25).

s. Receive the rights and decent work conditions, including decent working hours, overtime pay, weekly rest, paid vacation, occupational safety and health, security at the termination of employment, minimum age, and other working conditions under national legal practice (Article 25). 
t. Enjoy the same treatment as citizens in the country of work destination in terms of social security (Article 27).

u. Right to health care that is urgent for survival (Article 28).

v. Migrant workers' children have the right to name, birth registration, and citizenship (Article 29).

w. Children of migrant workers have the right to access basic education (Article 30).

$\mathrm{x}$. Transferring income, their personal belongings under the provisions of the applicable laws in the countries concerned (Article 32).

y. Information on the rights and obligations of migrant workers and members of their families (Article 33).

All of these articles regulate the rights of migrant workers and their entire families, both undocumented and undocumented. As for the rights of migrant workers and their entire family who are documented or in regular situations, state parties are obliged to fulfill other rights.

However, migrant workers have been protected under international law such as the International Convention on the Protection of Migrant Workers and Their Families. The role of the government in implementing the protection of migrant workers based on laws and other regulations still needs to be intensified. In the context of protecting Indonesian migrant workers, the Government of Indonesia provides two types of protection to migrant workers abroad.

First, preventive/educational protection that can be pursued through the creation of legal instruments to protect migrant workers, such as making laws regulating migrant workers and implementing regulations, making bilateral or multilateral agreements regulating the mechanism for the placement of migrant workers and their protection with users of migrant workers, and establishing organizations of migrant workers through migrant worker organizations in placement countries [11].

Second, repressive/curative protection can be realized by establishing a Crisis Center in sending and receiving countries in the context of dealing with legal, labor, and socio-cultural problems in the country, including migrant workers in insurance programs that can guarantee all work risks according to the type of work, and create or renew the moratorium.

Protection of migrant workers during work, which means protection after placement abroad based on Article 21 of Law no. 18 of 2017, including: a. data collection and registration by labor attaches or appointed foreign service officials; b. monitoring and evaluation of the employer, work, and working conditions; c. facilitating the fulfillment of the rights of Indonesian Migrant Workers; d. facilitate the settlement of labor cases; e. providing consular services; f. assistance, mediation, advocacy, and provision of legal assistance in the form of facilitation of advocate services by the Central Government and/or Representatives of the Republic of Indonesia as well as guardianship by local state law; g. guidance for Indonesian Migrant Workers; and h. facilitation of repatriation.

What is meant by "guidance" is the provision of activities to Indonesian Migrant Workers while they are in the destination country of placement. Meanwhile, what is meant by "facilitation of repatriation" is assistance provided to Indonesian Migrant Workers in the event of war, natural disasters, disease outbreaks, deportation, and Indonesian Migrant Workers experiencing problems [12].

Protection of Indonesian Migrant Workers while working is carried out without taking over the criminal and/or civil responsibilities of Indonesian Migrant Workers and is carried 
out under the provisions of laws and regulations, the laws of the country of placement destination, as well as international laws and customs [13].

Another form of protection for migrant workers while working abroad as regulated in Article 22 of Law no. 18 of 2017 is in the context of enhancing bilateral relations in the field of employment and the protection of Indonesian Migrant Workers abroad, the Central Government determines the position of labor attaché at Representatives of the Republic of Indonesia in certain countries. The assignment of labor attaches is carried out following the provisions of laws and regulations. An official who is appointed as a labor attaché has labor competence and diplomatic status.

Before migrant workers will work abroad, the Government has provided protection provided that Indonesian Migrant Workers can only work in countries of placement destination that [14]:

a. Have laws and regulations protecting foreign workers;

b. Has had a written agreement between the government of the country of placement destination and the government of the republic of indonesia; and/or

c. Have a social security and/or insurance system that protects foreign workers.

What is meant by "a written agreement between the government of the country of placement destination and the Government of the Republic of Indonesia" is an international agreement made in writing covering agreements in the field of public law, governed by international law, and made by the Government and the government of the country of placement destination [15].

It is worth noting that the 1990 ratification of the United Nations (UN) Convention on the Protection of the Rights of All Migrant Workers and Members of Their Families (Migrant Workers) does not fully guarantee that Indonesian workers (TKI) who work abroad will be protected. In this regard, the $1990 \mathrm{UN}$ Convention is not the answer to protecting migrant workers who work abroad. This is because all destination countries for placement of Indonesian migrant workers have not generally ratified the 1990 UN Convention which equates the rights and obligations of domestic workers and migrants.

By ratifying the $1990 \mathrm{UN}$ Convention, it will increase Indonesia's obligations internationally, especially for migrant workers from other (foreign) countries who are in Indonesia. Meanwhile, destination countries for the placement of Indonesian migrant workers, such as Malaysia, Japan, South Korea, Middle Eastern countries, and others, have no obligation to protect migrant workers from Indonesia according to international regulations. Moreover, until now the destination countries for the placement of migrant workers have not shown any desire to ratify the 1990 UN Convention. Developed countries, such as the United States (US) and the European Union (EU) have not ratified the convention.

A number of the basic principles and mandates of the UN Convention have been comprehensively stated in Indonesian laws and regulations, particularly in the labor sector. It has even adopted the principles contained in the International Labor Organization (ILO) convention on labor. This ratification of the 1990 UN Convention is indeed good for Indonesia's image in the world regarding human rights (HAM). However, the consequences will be additional obligations and facilities that Indonesia provides for foreign workers in Indonesia. Meanwhile, on the other hand, Indonesian migrant workers are not guaranteed protection under international regulations because no destination countries have ratified the convention. 
The protection of migrant workers depends entirely on the laws of the country of placement, as the jurisdiction of the person (migrant worker) is located. State jurisdiction refers to the state's authority to administer people and property by the application of its national laws (criminal law and civil law). It is argued that the jurisdiction of a country can only be limited to the territory of its country [16], so that in the context of citizen protection, the national law of the sending State cannot reach the national law of the receiving State. Therefore, in protecting migrant workers, cooperation or agreement (MoU) is required between the sending country and the receiving country.

Based on this, the Indonesian Government must work hard in efforts to protect migrant workers while working abroad. Especially for migrant workers who work in countries that have not ratified the 1990 UN Convention. Therefore, the efforts that must be made by the Indonesian Government in protecting migrant workers while working abroad include:

a. Uphold the role of the Manpower Attaché in the structure of the Indonesian Embassy, in supervising recruitment agencies, clarifying work placements, conducting visits to prospective employers, and following up on activities to provide better protection for Indonesian labor migrants in destination countries. Implement standard operating procedures at Indonesian Embassies abroad regarding cases of Indonesian labor migrants housed at the Indonesian Embassy, raise awareness of migrant workers about trafficking in persons or victims identified by attachés and consular staff, and how best to offer protection and assistance to migrant workers.

b. Improve coordination between the Government of Indonesia and the Indonesian Embassy and the Indonesian Consulate overseas in more effective cooperation to provide support for Indonesian labor migrants.

c. Create and maintain a blacklist of illegal recruitment agencies. Collaborating with the Ministry of Manpower and BNP2TKI.

d. Indonesian government representatives abroad ensure the application of international workplace standards in all destination countries.

e. Revise Law No.4 of 2008 concerning the Ministry of Foreign Affairs to ensure consistency that labor attaches at all Indonesian Embassies abroad have diplomatic passports.

f. Improve data collection on migrant workers carried out by the Government of Indonesia through an effective system for improving the protection of migrant workers.

Meanwhile, for the destination country, the following steps need to be taken:

a. If the country of destination does not want to ratify international conventions on migration issues, the main principles contained in the convention must be applied as national laws, policies, and procedures for each migrant-sending country, to improve the management of international migration under development goals.

b. Establish an MoU between Indonesia and destination countries to improve labor protection, based on the laws of the two countries, human rights, and international law.

c. To continue the bilateral agreement, there is a need to form an ASEAN regional agreement on the migration process, in which the recipient country will begin implementing laws that are favorable to the sending country, following the laws that are different in each country. 


\section{Conclusion and Suggestion}

\subsection{Conclusion}

The presence of Law Number 18 of 2017 concerning the Protection of Indonesian Migrant Workers in addition to the Manpower Act is evidence of the State's presence in addressing the issue of protection of Indonesian citizens who are looking for work abroad to fulfill their welfare. Protection of migrant workers while working abroad is the state's obligation to protect its citizens. This protection aims to ensure the fulfillment and enforcement of human rights as Indonesian citizens and Indonesian migrant workers, as well as ensuring legal, economic, and social protection.

\subsection{Suggestion}

To be more effective in the socialization of the protection of Indonesian migrant workers while working abroad by involving relevant stakeholders. Also, prospective migrant workers before working abroad must be given prior knowledge of labor regulations in the destination country, including the 1990 Migrant Workers Convention. This is to increase the knowledge concerned about the rights and obligations that must be carried out while working abroad.

\section{References}

[1] Undang-Undang Republik Indonesia Nomor 18 Tahun 2017 tentang Pelindungan Pekerja Migran Indonesia.

[2] Soejono dan H. Abdurahman.: Metode Penelitian Hukum. Rineka Cipta, Jakarta (2003).

[3] Marzuki, Peter Mahmud.: Penelitian Hukum. Edisi Revisi. Prenada Kencana, Jakarta (2014).

[4] Irsan, Koesparmono dan Armansyah.: Hukum Tenaga Kerja Suatu Pengantar. Erlangga, Jakarta (2016).

[5] International Labour Organization: Hak-hak Pekerja Migran Buku Pedoman Buruh. Terjemahan. ILO, Jakarta (2006).

[6] De La Vega, Connie, dan Conchita Lozano-Batista.: 21 Advocates Should Use Applicable International Standards to Address Violations of Undocumented Migrant Workers' Rights in the United States. dalam Human Rights and Refugees, Internally Displaced Persons and Migrant Workers, Editor: Anne F. Bayefsky, 517-50, Martinus Nijhoff Publishers (2016).

[7] Undang-Undang Republik Indonesia Nomor 18 Tahun 2017 tentang Pelindungan Pekerja Migran Indonesia.

[8] Undang-Undang Republik Indonesia Nomor 18 Tahun 2017 tentang Pelindungan Pekerja Migran Indonesia.

[9] Irsan, Koesparmono dan Armansyah.: Hukum Tenaga Kerja Suatu Pengantar. Erlangga, Jakarta (2016).

[10] Undang-Undang Republik Indonesia Nomor 18 Tahun 2017 tentang Pelindungan Pekerja Migran Indonesia. 
[11] Husni, Lalu.: Perlindungan Hukum Terhadap Tenaga Kerja Indonesia Di Luar Negeri, Mimbar Hukum. Volume 23, Nomor 11. Februari (2011)

[12] Undang-Undang Republik Indonesia Nomor 18 Tahun 2017 tentang Pelindungan Pekerja Migran Indonesia.

[13] Undang-Undang Republik Indonesia Nomor 18 Tahun 2017 tentang Pelindungan Pekerja Migran Indonesia.

[14] Undang-Undang Republik Indonesia Nomor 18 Tahun 2017 tentang Pelindungan Pekerja Migran Indonesia.

[15] Undang-Undang Republik Indonesia Nomor 18 Tahun 2017 tentang Pelindungan Pekerja Migran Indonesia.

[16] Wallace M.M., Rebecca and Olga Martin-Ortega.: International Law. Sixth Edition. Sweet and Maxwell, Thomson Reuters (2010) 